\title{
Innovation and Imitation for Global Competitive Strategies. The Corporation Development Models of US, Japan, Korea, and Taiwan
}

\author{
Silvio M. Brondoni ${ }^{*}$
}

\begin{abstract}
Globalisation has been driven by multinationals' capital and technology and produced a structural change in business networks. In this sense, one of the most important changes in industrial organisation is the transition from multinational corporations (MNCs) to global networks particularly focused on management of innovation and creative imitation.

The global competitive landscapes of innovation and imitation have significantly changed the relative position of many Nation-States.

The US corporations have changed their worldwide competitive position. Meanwhile the globalisation has expanded the market-space of corporations headquartered in countries with a high propensity to innovation (e.g. the Japanese companies), and has also promoted the growth of new countries, especially in the Far East (e.g. South Korea, India, Taiwan), where domestic firms have favorable conditions (especially in terms of social responsibility and low labor costs) to develop advanced skills for imitation and creative imitation.
\end{abstract}

Keywords: Global Competition; Innovation; Imitation; Creative Imitation; US Corporations; Japan Corporations; Korea Corporations; Taiwan Corporations

\section{The Knowledge Economy and the Global Networks}

Globalisation produced a structural change in business networks. The primacy of knowledge management, the worldwide localization of production and the new policies of innovation and imitation have been modified in opportunities for global competitive alliances and joint ventures (Brondoni 2012a). In this sense, one of the most important changes in industrial organisation is the transition from multinational corporations (MNCs) to global networks. Multinational corporations were characterized by the focus on stand-alone overseas investment plans. Global networks, on the other side, are characterized by the focus on coordinating and integrating their geographically dispersed supply, knowledge and customer bases

*Full Professor of Management, University of Milan-Bicocca (silvio.brondoni@ unimib.it)

Edited by: ISTEI - University of Milan-Bicocca

ISSN: 1593-0319

Brondoni Silvio M. (2013) Innovation and Imitation for Global Competitive Strategies. The Corporation Development Models of US, Japan, Korea, and Taiwan, Symphonya. Emerging Issues in Management (symphonya.unimib.it), n. 1, pp. $12-27$.

http://dx.doi.org/10.4468/2013.1.02brondoni 
into global network business activities (Canegrati 2012; Ernst, Kim 2001; Ernst 2001).

The transformation from MNCs to global networks moves towards vertical specialization and highly diversified patterns of collaboration across inter-firm and intra-firm transactions coordinated by global corporations (Luethje 2001). Global networks significantly reduced the importance of 'context specific skills'. The worldwide platform of Internet pushes the knowledge into a standardized format with minimal costs, and it can be readily transferred across country borders and firms, for which the business collaboration can take place between modules connected with each other with standardized interfaces (Hayashi 2002).

Globalisation has been driven by multinationals' capital and technology (Sigurdson 1990). As a result, traditional rules of oligopolies have totally changed, the links between firms have become strategic on a very large scale (Delapierre, Mytelka 1998), and industrial rivalry tends to occur among global networks comprising a multiplicity of firms linked up with different knowledge bases, particularly focused on management of innovation and creative imitation (Brondoni 2009; Chen, Chen 2001)

\section{Innovation, Imitation and Global Production Networks}

In global production networks, successful innovations interface many actors with different knowledge and skill bases. Innovations are complex technical systems, comprising a set of interdependent products that are jointly realized by networked firms (Windrum, Tomlinson 1999). Consequently, innovations usually originate from the collective efforts of inter-related firms, and the innovation value chain is not completely internalized within individual firms. Therefore, industrial competition more and more takes place between rival technological and production networks defined by a large number of differentiated firms rather than between vertically integrated oligopolists, and this continuous disintegration of production and innovation capabilities reshaped the landscape of global competition (Feenstra 1998).

$\square$ 'When West Europe regained its economic momentum after World War II, international economic relationships were featured by a SouthNorth divide; the industrialized economies in the developed world versus agriculture-based production in the developing countries. The resurgence of Japan and the rise of Newly Industrializing Countries (NICs) between the 1960s and the 1990s has brought the new era... leading to the trend of global manufacturing capabilities being increasingly diffused from the developed countries to the developing world... as the Latin American NICs have adjusted their developmental strategy toward an outward one, and as developing countries in East Asia such as Malaysia, Thailand, China have followed the footstep of the four Asian Tigers to pursue export-oriented industrialization, not only have manufacturing capabilities been further disintegrated globally but also the pressure of industrial competition from the developing world has intensified' (Chen, Chen 2001). 
Global firms have reoriented their competitive strategies. Many US firms and more recently Japanese corporations have increasingly adopted offshore sourcing (Kotabe 1996; Swamidass, Kotabe 1993; Venkatesan 1992). Many marketers concentrated on brand equity and R\&D competencies while outsourcing the rest of the production, surrendering the vertical integration of traditional multinationals (Kotabe 1989) and generating global networks with fast-response capabilities of logistics services to provide production and marketing.

In open markets where competition is strong, innovation therefore loses its role of 'ideological hierarchy' over imitation; both have the common goal of maximising company profitability, with the constraint of optimising performance results in the very short term. With these objectives and constraints, the success of research and development activities is measured by the capacity to exploit the competition, while the capacity to accumulate know-how becomes less important (for example with the traditional indicators of the number of patents per year) (Brondoni 2012a).

Global production networks actually identify different categories of imitations: product pirates, or counterfeits; clones, or knockoffs; design copies; creative adaptations; technological leapfrogging; and adaptation to other industry.

Counterfeits and knockoffs are duplicative imitations, but only the first is illegal. Counterfeits are copies that merely imitate an original brand. In contrast, knockoffs are legal products that closely copy the original products in the absence of copyrights, trademarks and patents and sell them with their own brand names at far lower prices. Knockoffs often present a better quality than original products. Therefore, when it is legal, duplicative imitations are a bright strategy for the firms with low wages and mature technology (Schnaars 1994).

On the contrary, global networks consider as creative imitations the imitative products regarding: design copies; market adaptations; technological leapfrogs; and adaptations to another industry.

Design copies follow the market leader but stay on the market with their own brand name and specific engineering features. Product adaptations are innovative, with improvements inspired by existing products. Technological leapfrogs get advantage with newer technology and enable the imitator to leapfrog the innovator. Finally, adaptations to another industry take on the application of innovations in a certain industry for using them in another. In general, creative imitations are focused on generating imitative products, but with new features. These imitative products involve benchmarking, strategic alliances, and substantial investments in R\&D (Bolton 1993).

Competitive global networking emphasizes the relation between innovation and imitation. The management of global innovation and imitation is driven by competition, through continuous increases in technological advances and accelerating life cycles of customer preferences (Brondoni 2012b).

\section{Global Corporate Policies of Innovation and Imitation}

Global corporate policies of innovation can be summarized in:

- Global product innovation. The creative development of a new product grounded on new technology and linked to unmet customer needs. Product innovation, research and development are targeted to create products destined to 
break the existing continuity in the link between supply and demand (breakthrough), and, naturally, even between competitors (Aaker 2005).

- Global process innovation. The development of new ways of producing products that leads to advantages on costs, time or quality, where costs devoted to product development take priority. Global process innovation targets the investments in development and research to create products that are destined to maintain the existing relationship between supply and demand, improving only the competitive advantage provided by the product's distinctive features.

- Global competitive innovation. Large corporations with heavy investments on D\&R pursue global policies of competitive innovation when corporate growth is focused on the development and research of products specifically designed and produced jointly with competitors.

Therefore, the imitation processes are the result of corporate strategies created by largest corporations to compete and to grow on global and over-supplied markets (Nonaka, Takeuchi 1995; Sinclair 1990).

Conversely, global networks define the corporate policies of imitation as:

- Global product imitation. With the global product imitation, firms pursue a competitive policy as followers, to reduce $R \& D$ costs, to minimise the risk of acceptance of a product on different markets, and finally to choose the right moment' to enter a market (time-based competition). Development and research activities of global product imitation are focused on increasing the quantities of specific products offered pursuing global competitive policies based on oversupply.

- Global process imitation. Products designed and manufactured in massive quantities imitating similar products. Global process imitation pursues a policy of corporate growth, in markets that are in recession and over-supplied, with a competitive advantage based on products obtained with highly imitative manufacturing processes. Global process imitation expresses a very aggressive competitive policy, directed at implementing a range of highly profitable products, made up of products that are poorly differentiated and designed to satisfy very similar needs and preferences.

- Global competitive imitation. Products designed and assembled in close collaboration with competitors. This policy demands high investments in D\&R, aimed at creating products with high commercial margins and with high short-term returns on the capital invested. Global competitive imitation policies based on global cooperative alliances allow global players to share the risks of launching and handling imitative products on a vast scale.

\section{Global Competitive Landscapes of Imitation and Innovation}

Global markets impose an important transformation of the firm's growth policies where innovation and imitation (of products and processes) play a primary role in meeting a volatile demand in markets with over-abundance of production.

Market globalisation and the corporation's growth objectives step up the management complexity, determining new competitive landscapes in corporate strategies connected with imitation and innovation (Corniani 2012). 
In the global world, corporations copy and succeed, because the capacity to exploit the competition acquires prime importance, while the capacity to achieve innovative know-how becomes less important.

In open markets where competition is strong, the firm profit and development objectives are increasingly at odds with the growth constraints of the corporate financial objectives. To overcome this dualism, firms are induced to target R\&D spending on open innovation policies in which: the boundaries between imitation and innovation are fluid; the profit level of the innovation/imitation initiatives is an absolute priority; and finally, a return on investment can be achieved in the very short term (Brondoni 2011).

In fiercely competitive global markets, the $R \& D$ activities therefore become a key-intangible asset, whose role is to develop the firm innovation and imitation policies, to anticipate demand trends and the initiatives of the competition, even collaborating with key competitors on particular projects.

What is more, growth objectives and short-term profitability constraints prompt large corporations to favour multipolar development of R\&D activities that focus on global imitation and innovation policies. This multipolar development encourages the creation of decentralised technological development structures (Corniani 2011; Cappellin, Wink 2009), which operate with multi-ethnic personnel and are located in the most important world cities, a centre of gravity that is shifting from Europe to the global cities of Southeast Asia and North and South America (Brondoni 2011).

In global managerial economics, knowledge production becomes the critical competitive factor and forces the Nation-States to develop a global perspective in developing large cities, to be leader in knowledge production (world cities), designed to meet the growing needs of global networks (He, Xiao Xiaojun 2011; Brondoni 2011).

\section{Global Corporate Policies of Innovation and Imitation. The Drivers of U.S. Global Corporations}

The US corporations maintain the primacy of innovation in global markets. USbased firms have also been the undisputed leaders of next-generation technology (from IT to space, to semiconductors).

Recently, moreover, McKinsey Global Institute conducted a research on the role of US multinationals, with in-depth interviews in advanced industrial companies, leader in R\&D and engineering-intensive, ranging from automobile and energyequipment manufacturers to aerospace and defense players. From this research, McKinsey Global Institute queries whether the US firms lost their capacity to translate innovation investments into a profitable leadership (Manyika et al. 2011).

Innovation may indeed create profits, but it is only part of the economic engine, because abilities to take basic innovation, produce it in an economic scale, and sell it globally, all play a critical role in driving economic and social growth. To do all this, a national innovation system must be at the center of cutting-edge technologies, market demand, talent, and entrepreneurial spirit (Manyika et al. 2011). 
In the current state of competitive globalisation, the main drivers of US firms for global corporate policies of innovation and imitation can be summarized in:

- Focus on short-term returns for innovation and imitation. US-based global firms continuously need to reinvent product offers and innovation is becoming the milestone for success. This new competitive landscape changes the nature of innovation. Many companies will maintain their competitiveness by acquiring small, entrepreneurial firms in new markets where building competencies themselves would simply take too long. Companies are finding that they need to be innovative just to keep their core businesses relevant. The firm R\&D strategy is to become more innovative and more flexible.

- Oblique competition. Global markets have changed also the nature of competition. Global competition can come from nowhere and take over whole market segments. Corporations compete within industries, but company most important competitors may not even be in the same industry (Brondoni 2005). Oblique competition expands the competitive landscape and the competitive edges that business policy will have to pay attention to in terms of innovation, creative imitation and duplicative imitation.

- Fracturing mass markets to manage demand bubbles. More and more, local markets and market segments will shatter, making corporations accustomed to drive mass markets managing demand bubbles (Corniani 2005).

\section{$\square$ In health care, the rise of specific diagnostics means that smaller numbers of customers are likely to respond to a given therapy.}

Firms must profit by serving customers profiles with personalized offers, together with broad markets. This fracturing of mass markets will favor corporations that sell mass products and at the same time customize customers' particular desires and tailor production accordingly, with corporate policies of creative imitation.

- Task on flexible assets and capabilities. In global competition, corporations avoid fixed-amount commitments to specific assets and capabilities and the same applies to people. More and more real work is being done on outsource processes or by people on a freelance or part-time basis. The fundamental driver is that in hard competition, firms search to preserve their management flexibility by not owning many assets (McGrath 2011).

- Diffusion of standards based on essential patents. In the global competitive contest, large US firms, the historical innovators, are worried by the cost of innovation and by the uncertainty about public policy and regulation. For these reasons, US global corporations require a national commitment in which corporations and public authorities define standards focused on protection of innovation investments. Standards can be defined as "... specifications that establish the fitness of a product for a particular use or that define the function and performance of a device or system" (NITS 2010). In the actual global competition, standards are a key-factor for investment in innovation and in creative imitation. Standards facilitate indeed data exchange as well as knowledge sharing among geographically dispersed participants within global corporate networks of production and innovation, to maximize the benefits of network externalities (Ernst 2001). Standards based on 'essential patents' are designed to block competitors and to deter new entrants. In fact, 'platform leadership' strategies are directed to 
leverage the market power of industry leaders into the control of systemic architectural innovations (Ernst 2012).

Intel has attempted to extend its control over microprocessors by creating widely accepted architectural designs that increase the processing requirements of electronic systems and, hence, the market for Intel's microprocessors (Wang et al. 2010).

In short, from a general point of view, US-based global production networks are primarily focused on incremental innovation ('creative imitation') and especially on the defence of property rights of basic 'essential patents'. By consequence, in these last years the US global firms directed their competitive policies to maintain a market-leader position both on economies of scarcity (i.e. petroleum) and on economies with controlled competition (i.e. health products, or global products for smokers). US global firms are anyway very prudent to innovate globally, and they prefer to produce and to sell across the globe by parent companies.

\section{Global Corporate Policies of Innovation. The Drivers of Japanese Global Corporations}

Japanese global corporate policies of innovation are characterized by:

-Vertical integration. The 'Keiretsu', both vertical and horizontal, allow supply chain with global economies of scale related to innovation corporate policies. The 'Keiretsu' also favour corporate policies of 'creative imitation', as a consequence of 'relapse cascade' of innovations in network companies belonging to sectors of activity different from the source of innovation (Berglof, Perotti 1994);

-Corporate growth without external merger \& acquisition. The policies of business growth show a very low use (often non-existent) of mergers and acquisitions neither of local companies, nor of firms with different culture and values (Furlan 2002);

-Competitive edge on market-driven management (Exports, Products zerodefects, Cost Reduction, Time-Based Competition). The competitive strategy of Japanese networks is based on continuous exports of largest markets, (Kim, Oh 2002), focusing on fundamental characters of the products, made with very high quality standards and with production processes aimed at minimizing the cost, in a vision of competitive primacy (Market-Driven Management) (Gnecchi 2008; Lambin, Brondoni 2001);

-Absence of marketing management culture. It is not surprising that, despite the advanced state of market-driven management (Brondoni 2008) in Japanese businesses, just a few numbers of theoretical and empirical studies have been produced in this country in terms of unique contributions to marketing management theory. Marketing management textbooks abound, but their contents largely derive from the United States, and they are more interested in sales organisation rather 
than in customer satisfaction. International marketing and global marketing are also fields where theoretical developments have been far outpaced by business practices of Japanese global corporations, confirming the success of Japanese exporting companies based on a strategic posture dominated by a long-run perspective and a high quality/price ratio in products (Johansson, Nonaka 1983);

\begin{abstract}
"An academic tradition (a relic from the $19^{\text {th }}$ century) puts higher values to theories and research findings of scholars abroad than those developed by the Japanese. A young academic gains more recognition by introducing latest theories and research findings by foreign scholars to Japan, than by developing an original theory and testing it. Even an established scholar feels little pressure to publish his work outside Japan and participate in the advancement of the field of marketing" (Nakanishi 1981).
\end{abstract}

-Innovation and creative imitation. The global network-based mass-production of Japanese corporations presents two aspects that underpin the importance of global innovation policies: 1 . The vertical specialization of $R \& D$. For complex systems, product technology development is becoming more and more modularized, and the design processes are performed on a commodity base, usually made by external, specialized subcontracting firms. This modularization is making engineering work more easily transferable resulting in the relocation of important elements of the chain of knowledge production to low-cost locations; 2. The separation of $R \& D$ (centralized on vision, mission, and strategies) from operations (organized by contract manufacturing firms) and from sales (performed by own companies with global standards and local sales organisations).

In brief, from a general point of view, Japanese global production networks are focused primarily on innovation and breakthrough, and they compete innovating globally, and producing or selling across the globe by own companies. The management of global continuous innovation (breakthrough or incremental creative imitation) is driven by competition, increases in technological advances and accelerating cycles of customer preferences (Rieple et al. 2012).

\title{
7. Global Corporate Policies of Creative Imitation and Innovation. The Drivers of South Korea's Global Corporations
}

The following main drivers characterize the South Korean global corporate policies of creative imitation and innovation:

- Firm growth driven by chaebols power. The South Korea chaebols are similar to Japan's post-war conglomerates (Keiretsu). In the 1960s and 1970s, South Korea industrialized rapidly by copying the Japanese international model of economic growth. As a matter of fact government provided funding to the chaebols to encourage production of consumer goods for export, at the beginning simply based on imitation (international trade), but more recently also based on creative imitation (global markets). 
Actually, the largest chaebols are focusing their enterprises on the following global businesses:

* Hyundai: construction, automobiles, heavy industry, electronics and finance;

* LG Group: information technology and telecommunications, electronics, biotechnology;

* Daewoo: automobiles, electronics, construction, information technology, telecommunications;

* SK Group: energy, finance, information technology and telecommunications.

* Samsung: electronics, engineering, heavy industries, petrochemicals, securities, investment trust management, venture investment, engineering \& construction, healthcare, medical, Renault Samsung motors, Sungkyunkwan University.

$\square$ 'Under pressure to trim back and reduce debt, the giant Samsung Group may give up its plan to build a 102-story office tower here but will continue a controversial automotive venture as well as its distribution, finance and semiconductor. Many South Koreans criticized Samsung's decision to enter the capital-intensive automotive sector at a time when Kia and other South Korean automakers were struggling and there was a worldwide glut of vehicles. But that venture is a pet project of Samsung Chairman Lee Kun Hee, who has invested $\$ 1.8$ billion into a new automobile manufacturing plant in Kwongsang Province' (Iritani 1998).

- Chaebols orientation to export mass market. Chaebols followed the government export-oriented policies, which were very coherent with the world economic trends. Chaebols, in their first period of international selling, started to lead the economic development of South Korea through the imitation strategy of mass-market products. The shift from international markets to global competition forced chaebols to invest massively on $\mathrm{R} \& \mathrm{D}$, and cooperate with some public R\&D institutions established by the government then, with the task of pursuing corporate strategies of mass-market productions based on high innovation or on creative imitation of established products.

$\square$ On August 24, 2012, a U.S. court ruled against Samsung to pay $\$$ 1.05 billion in damages to Apple Inc... for violating six of its patents on smartphone technology. The decision also ruled that Apple did not infringed Samsung patents. Shortly thereafter, a judgment of a South Korean court said that the two companies were guilty of violating each other's intellectual property

- Corporate growth without external mergers \& acquisitions. In early 1980s (at the beginning of globalisation) when US international firms collapsed, chaebols adapted to the declining trend of US-based manufacturing industry by such expansion strategies as the horizontal and vertical integration, and related and unrelated diversification during 1980s-1990s (so called octopus' expansion).

Hyundai favors long-term relationships with its suppliers and deepens their manufacturing processes to improve quality output at a 
lower price. The stability and quality of the supply base enable suppliers to produce modular subassemblies, reducing assembly time on the Hyundai production line. The plant also makes extensive use of robots. A robot twists and grabs a complete dashboard, then twists it again and installs the dashboard in the car. This production process takes just a few seconds, but would take two people half a minute.

In these last years, chaebols continued to expand their global business through the incremental innovation strategy (creative imitation) and the historical imitation policy, managing the diversified business portfolios with a 'centralized decisionmaking' structure and decentralized sales organisations'.

Samsung Electronics Co. has applied for U.S. and South Korean trademarks for a watch that will be "capable of providing access to the Internet, for sending and receiving phone calls, electronic mails and messages" as well as "for keeping track of or managing personal information." Samsung described "Samsung Galaxy Gear" as a wearable digital electronic device in the form of a wristwatch, wristband or bangle in its 2013 July 29 application with U.S. Patent and Trademark Office. A month earlier, it applied for a "Samsung Gear" trademark in South Korea. The tech industry experts expect there will be a new generation of mobile technology that dramatically expands the utility of single-function objects such as watches and glasses.

- Corporate marketing culture focused on sales and exports. South Korean corporations make no secret of their aggressive marketing and promotion strategies. The marketing strategy of South Korean chaebols is targeted on projecting a simple image they aspire to: being innovative. At the same time, the sale strategy of making their products available at every useful point of sale has proven to be quite accurate and very aggressive.

Samsung has expanded its range of mid-priced smartphones to capture sales in blooming markets such as China and India. Samsung sells in US market at least 40 smartphone models. That compared to about 25 HTC devices.

$\square$ Hyundai, considered in the 1990s as a producer of low-quality cars and in the 2000s as a 'me-too' follower of Honda and Toyota, has become the fastest-growing automotive global brand. Hyundai has been able to step out from behind its larger Japanese competitors and impose a style leadership because of the culture of creativity that has been developed in its design center. At the same time, Hyundai has learned how to motivate local organizations to compete. The combination of central control and local responsiveness has given the firm the skills to pick up local signals and rapidly turn them into product designs. Hyundai Motor confined itself to Asian markets until 1986 and purchased KIA Motors Corporation in 1997. Starting in 


\begin{abstract}
1998, once customers were convinced of the brand reliability, Hyundai added other capabilities, such as design, which led to a more diversified product line and more stylish features. Meanwhile, it developed an aggressive, consistent marketing. The result is a coherent mix of quality improvement, design, and marketing that gives Hyundai a clear advantage over its industry competitors. Hyundai set aggressive price for its vehicles at the same time that it maintains high profit margins.
\end{abstract}

In the last 15 years, South Korea played an important role in the new global competition by challenging the country intermediate position between its main export-competitors, low-wage China and high technology Japan.

Edging the technological frontier, South Korea approached very important changes in qualifying productivity growth, and in using corporate finance for the global product commercialisation.

In brief, South Korean global networks are at present focused primarily on creative imitation of mass-market established products, but their competitive policies are directed more and more to innovative production, characterised by high R\&D investments and hard global selling.

\title{
8. Global Corporate Policies of Imitation and Innovation. The Drivers of Taiwan's Global Corporations
}

Since the 1980s, the information industry has increasingly become the engine of economic growth in Taiwan, and Taiwan is currently considered one of the largest producers in the worldwide information industry. This outstanding performance derived mainly from the production of PCs, within these sectors, such as motherboards, scanners, monitors, and notebook computers, peripheral equipment and sub-sectors, and quite a number of Taiwanese-made products enjoy significant global market shares. Taiwan has followed a development strategy similar to Korea's, with the same open vulnerabilities, but with a considerably more advanced financial system. (Hobday 1995; Kim, Tunzelmann 1998).

The following main drivers characterize the Taiwan's global corporate policies of imitation and innovation at present:

- Flexible specialisation. In contrast to the dominance of vertically integrated conglomerates in Korea and Japan, Taiwan's industries consist of many small firms specialized within a narrow range of the value chain activities, such as design, mask production, packing and testing. In a sense, Taiwan's industry is organised by an industrial network system with strong connections. For example, the geographical concentration of Taiwan's IC and computer-related firms in a specific industrial park has generated agglomeration effects, allowing those firms to explore the benefits associated with geographical proximity and outsourcing.

- Global production \& logistic networks. An important milestone in the development of Taiwan's information industry is the outreach of its constituent firms starting from the late 1980s. As the ability to manufacture PCs has become widely diffused throughout the world, as price competition has intensified, and as profit margins have narrowed for most mature computer technologies, the PC 
industry has witnessed a profound change in inter-firm competition and its manufacturing systems, with the emergence of global production networks - global logistics (Chen, Liu 2003, Chen, Liu 2000).

$\square$ Compaq pioneered the so-called optimized distribution model (ODM). This model is based on: 1. production is required to meet orders (build-to-order) rather than forecasts (build-to-forecast), to restrict the gap between demand and supply; 2. customized products are produced in specific quantities to meet the variety of customer demands; 3. Compaq's vendors are required to undertake final assembly, bringing together a set of modular subassemblies produced and delivered by Compaq's subcontractors. From Compaq's perspective, the adoption of ODM enables it to concentrate on its own core competencies of $R \& D$ and marketing whilst leaving the rest of the value chain to its subcontractors in Taiwan and to vendors. Compaq has completely handed its inventory costs over to its subcontractors, whilst the latter are also required producing and delivering subsystem products in line with tight schedules and the variety of market demand.

To serve their customers, global subcontractors, such as those based in Taiwan, have had to establish a well-structured, fast-response global production and logistics network through the formation of strategic alliances. As a result, the production system has become a global 'just-in-time' operations model. With globalisation, the relationship between Taiwanese firms and their customers has gone beyond the traditional original equipment manufacturing model (OEM). Under OEM contracting, firms are just providers of finished products. In contrast, global logistics contracting requires Taiwanese subcontractors to take on much greater responsibility by participating in supply-chain management, logistics operations and after-sale services. Both sides of the contractual relationship have to work closely together and link themselves, upstream to R\&D and downstream to distribution and logistics. However, the global logistics system of Taiwan-based firms mobilizes resources from its global network to undertake the production process. In other words, Taiwanese products will be the result of the productive and innovative efforts of a variety of firms and economies around the world.

Therefore, in brief, Taiwan's industry has evolved from a distant-follower (primarily focused on imitation) to become an immediate follower, with important investments in $\mathrm{R} \& \mathrm{D}$ dedicated to the product creative imitation and to the product/process innovation.

\section{Concluding Remarks and Emerging Issues}

The global competitive landscapes of innovation and imitation have significantly changed the relative position of many Nation-States. Firstly the United States changed their worldwide competitive position. US in the past had ruled the diffusion of innovations and the 'block' of imitations, but now they have lost their historical leadership and are looking for a new role in the control of the innovation and imitation processes. 
The US corporations maintain the primacy of innovation in global markets, and US-based firms have been the undisputed leaders of next-generation technology (from IT to space, to semiconductors).

In US corporations there are many warning signs, however, across the leadership on industrial innovation. US companies can no longer build products just for the US market and the composition of global demand has dramatically changed over the past few decades.

In leading industrial technologies (such as hybrid automobiles, high-speed rail, solar modules, and wind turbines) the US-based firms compete against foreign companies. The new 'global model' of production network (e.g. the worldwide automobile industries) changed anyway the rules of corporate innovation management, with a continuous spillover of incremental innovations and imitations.

In the new competitive contest, large US firms, the historical innovators, seem most affected and worried by the cost of innovation and by uncertainty about public policy and regulation. US global firms are very prudent to innovate globally, and they prefer to produce and to sell across the globe by parent companies.

From a general point of view, US-based global production networks are primarily minded on incremental innovation ('creative imitation') and especially on the defence of property rights of basic 'essential patents'. In this sense, standards are in these last years the most competitive edge for US global corporations to protect innovation in the global knowledge economy.

Conversely, Japanese global production networks are focused primarily on innovation and breakthrough, and their competitive policies do not only innovate globally, but also produce or sell across the globe by own companies.

In the same direction, the South Korea global corporations focused their policies on creative innovation and, more recently, on innovation. South Korean Chaebols industrialized rapidly by copying the Japanese international model of economic growth, and they in the first period of international selling adopted the imitation strategy of mass-market products. In the last 10-15 years, the shift from international markets to global competition forced chaebols to invest massively on $\mathrm{R} \& \mathrm{D}$, with the task of pursuing corporate strategies of mass-market productions based on creative imitation and, more and more, on innovation.

Finally, Taiwan's industry has evolved from a distant-follower (primarily focused on imitation) to become an immediate follower (with a specific model of development), with important investments in $R \& D$ dedicated to the product creative imitation and to the product/process innovation.

Briefly, globalisation has expanded rapidly the market potential of corporations headquartered in countries with a high propensity to innovation (e.g. the Japanese companies), and has also promoted the growth of new countries, especially in the Far East (e.g. in South Korea, India, Taiwan), with favorable market conditions (especially in terms of low labor costs) to develop advanced skills for imitation and creative imitation.

Conversely the main European countries (such as UK, Germany and Russia) lost their leadership in innovation, although they played a leading role in the development of last century closed markets. Italy too lost its primacy in craftsmanship in spite of its important industrial history based on creative skills famous in the world. (Brondoni 2012c). 


\section{Bibliography}

Aaker David A. (2005) Strategic Market Management, J. Wiley \& Son, Chichester.

Berglof Erik, Perotti Enrico (1994) The Governance Structure of the Japanese Financial Keiretsu, Journal of Financial Economics, October, vol. 36, 2, pp.259-284. http://dx.doi.org/10.1016/0304-405x(94)90026-4

Bolton Michele K. (1993) Imitation versus Innovation: Lessons to Be Learned from the Japanese, Organizational Dynamics, Winter, pp. 30-45. http://dx.doi.org/10.1016/j.bbr.2011.03.031

Brondoni Silvio M. (2012a) Innovation and Imitation: Corporate Strategies for Global Competition, Symphonya. Emerging Issues in Management (symphonya.unimib.it), n. 1, pp. 10-24. http://dx.doi.org/10.4468/2012.1.02brondoni

Brondoni Silvio M. (2012b) Managerial Economics and Global Corporations, Giappichelli, Turin.

Brondoni Silvio M. (2012c) Market-Driven Management and Corporate Growth, Giappichelli, Turin.

Brondoni Silvio M. (2011) Global Networks, Knowledge Management and World Cities, Symphonya. Emerging Issues in Management (symphonya.unimib.it), n. 1, pp. 7-18. http://dx.doi.org/10.4468/2011.1.02brondoni

Brondoni Silvio M. (2009) Market-Driven Management, Competitive Customer Value and Global Networks, Symphonya. Emerging Issues in Management (symphonya.unimib.it), n. 1, pp. 8-25. http://dx.doi.org/10.4468/2009.1.02brondoni

Brondoni Silvio M. (2008) Market-Driven Management, Competitive Space and Global Networks, Symphonya. Emerging Issues in Management (symphonya.unimib.it), 1, pp. 14-27. http://dx.doi.org/10.4468/2008.1.02brondoni

Brondoni Silvio M. (2005) Managerial Economics and Global Competition, Symphonya. Emerging Issues in Management (symphonya.unimib.it), n. 1, pp. 14-38.

http://dx.doi.org/10.4468/2005.1.02brondoni

Canegrati Tino (2012) Global Account Management for Sales Organization in Multinational Companies, in Silvio M. Brondoni (ed.), Market-Driven Management and Corporate Growth, Giappichelli, Turin.

He Canfei, Xiao Xiaojun (2011) Geography of Multinational Corporations and Functional Specialization in Chinese Cities, Symphonya. Emerging Issues in Management (symphonya.unimib.it), n. 1, pp. 29-40

http://dx.doi.org/10.4468/2011.1.04he.xiao

Cappellin Riccardo, Wink, Rudiger (2009) International Knowledge and Innovation Networks: Knowledge Creation and Innovation in Medium Technology Clusters, Edward Elgar Publishing, Cheltenham,

Chen Shin-Orng, Liu Meng-chun (2003) Taiwan's Transition from an Industialising Economy to a Knowledge-based Economy, in Seiichi Masuyama,Donna Vandenbrink (eds.), Towards a Knowledge-based Economy: East Asia's Changing Industrial Geography, Institute of Southeast Asian Studies \& Nomura Research Institute, Singapore \& Tokyo.

Chen Shin-Orng, Liu Da-Nien (2000) Taiwan's Active Role in the Global Production Network, in Peter C. Y. Chow, Bates Gill (eds.), Taiwan, Its Neighbors, and the Asian Financial Crisis, The Brookings Institution, Washington.

Chen Tain-Jy, Chen Shin-Horng (2001) Global Production Networks and Local Capabilities, East West Center Working Papers, Economics Series, n. 15, February.

Corniani Margherita (2012) Innovation, Imitation and Competitive Value Analysis, Symphonya. Emerging Issues in Management (symphonya.unimib.it), n. 2, pp. 37-52. http://dx.doi.org/10.4468/2012.2.04corniani

Corniani Margherita (2011) Shopping Centres and Intangible Consumption in Global Cities, Symphonya. Emerging Issues in Management (symphonya.unimib.it), n. 1, pp. 41-54 . http://dx.doi.org/10.4468/2011.1.05corniani 
Corniani Margherita (2005) Market, Demand Segments and Demand Bubbles, Symphonya. Emerging Issues in Management (symphonya.unimib.it), n. 2, pp. 13-30. http://dx.doi.org/10.4468/2005.2.02corniani

Delapierre Michel, Mytelka Lynn K. (1998) Blurring Boundaries: New Inter-Firm Relationships and the Emergence of Networked Knowledge-Based Oligopolies, in M.G. Colombo (ed.), The Changing Boundaries of the Firm: Explaining Evolving Inter-Firm Relations, Routledge, New York.

Ernst Dieter (2012) America's Voluntary Standards System: A "Best Practice” Model for Innovation Policy?, East West Center Working Papers, Economics Series, n. 128, February, Honolulu.

Ernst Dieter (2001) The Evolution of a 'Digital' Economy': Research Issues and Policy Challenges, Economia e Politica Industriale, pp. 127-138.

Ernst Dieter (2001) The New Mobility of Knowledge: Digital Information Systems and Global Flagship Networks, East West Center Working Papers, Economics Series, n. 30, July, Honolulu.

Ernst Dieter, Linsu Kim (2001) Global Production Networks, Knowledge Diffusion, and Local Capability Formation: A Conceptual Framework, East West Center Working Papers, Economics Series, n. 19, May, Honolulu.

Feenstra Robert C. (1998), Integration of Trade and Disintegration of Production in the Global Economy, The Journal of Economic Perspectives, vol. 12, 4, pp. 31-50. http://dx.doi.org/10.2307/i345526

Furlan Umberto (2002) Corporate Culture and Global Competition. The Honda Philosophy, Symphonya. Emerging Issues in Management (symphonya.unimib.it), n. 2, pp. 34-43. http://dx.doi.org/10.4468/2002.2.05furlan

Gnecchi Flavio (2009) Market-Driven Management, Market Space and Value Proposition, Symphonya. Emerging Issues in Management (symphonya.unimib.it), n. 2, pp. 33-45. http://dx.doi.org/10.4468/2009.2.04gnecchi

Hayashi Takashi (2002) Production Networks of Japanese and American Automobile Industry: Contrasting Evolution and Convergence, East West Center Working Papers, Economics Series, Economics Series, n. 45, May, Honolulu.

Hobday Mike (1995) Innovation in East Asia: The Challenge to Japan, Edward Elgar, Aldershot.

Johansson Johny K., Nonaka Ikujiro (1983) Japanese Export Marketing: Structures, Strategies, Counterstrategies, International Marketing Review, vol. 1, 2, pp. 12-25.

http://dx.doi.org/10.1108/eb008248

Kim Keysuk, Oh Changho (2002) On Distributors Commitment in Marketing Channels for Industrial Products: Contrast between the United States and Japan, Journal of International Marketing, vol. 10, n. 1, pp. 72-97. http://dx.doi.org/10.1509/jimk.10.1.72.19530

Kim S. Ran, von Tunzelmann Nick (1998) Aligning Internal and External Networks: Taiwan Specialization in IT, SPRU, University of Sussex: Brighton.

Kotabe Masaaki (1996) Global Sourcing Strategy in the Pacific: American and Japanese Multinational Companies, in G. Boyd, (ed.), Structural Competitiveness in the Pacific, Edward Elgar, Cheltenham.

Kotabe Masaaki. (1989) 'Hollowing-out' of US Multinationals and their Global Competitiveness, Journal of Business Research, August, vo1.19, 1, pp.1-15. http://dx.doi.org/10.1016/0148-2963(89)90037-4

Lambin Jean-Jacques, Brondoni Silvio M., Ouverture de 'Market-Driven Management', Symphonya. Emerging Issues in Management (symphonya.unimib.it), n. 2, 2000-2001, pp. 1-11 http://dx.doi.org/10.4468/2001.2.010uverture

Luethje Boy (2001) Electronics Contract manufacturing: Transnational Production Networks, the Internet, and Knowledge Diffusion in Low-Cost Locations in Asia and Eastern Europe, East West Center Working Papers, Economics Series, No. 17, April, Honolulu.

Manyika James, Pacthod Daniel, Park Michael (2011) Translating Innovation into US Growth: An Advanced-Industries Perspective, McKinsey \& Company, May.

McGrath Rita (2011) Five Big Trends in Business Innovation in 2012, FORBES, 19 December. 
NIST-National Institute of Standards and Technology (2010) Framework and Roadmap for Smart Grid Interoperability Standards, National Institute of Standards and Technology, US Department of Commerce, Washington, D.C., January, pp.19-20.

Nonaka Ikujiro, Takeuchi Hirotaka (1995) Knowledge Creating Company: How Japanese Companies Create the Dynamics of Innovation, Oxford University Press, New York.

Nakanishi Masao (1981) Marketing around the World, Journal of Marketing, Summer, vol. 45, pp. 206-218.

Rieple Alison, Pironti Marco, Pisano Paola (2012) Business Network Dynamics and Diffusion of Innovation, Symphonya. Emerging Issues in Management (symphonya.unimib.it), n. 2, pp. 13-25. http://dx.doi.org/10.4468/2012.2.02rieple.pironti.pisano

Schnaars Steven P. (1994) Managing Imitation Strategy: How Later Entrants Seize Markets from Pioneers, The Free Press, New York.

Sigurdson Jon (1990) The Internationalization of R\&D - An Interpretation of Forces and Responses, in J. Sigurdson, (ed.), Measuring the Dynamics of Technological Change, Pinter, London.

Sinclair Peter J. N. (1990) The Economics of Imitation, Scottish Journal of Political Economy, May, pp. 113-144. http://dx.doi.org/10.1111/j.1467-9485.1990.tb00577.x

Swanmidass Paul M., Kotabe Masaaki (1993) Component Sourcing Strategies of Multinationals: An Empirical Study of European and Japanese Multinationals, Journal of International Business Studies, Vo1.24, No.1, pp.81-100. http://dx.doi.org/10.1111/10.1057/palgrave.jibs.8490226

Venkatesan, Ravi (1992) Strategic Sourcing: To Make or not to Make, Harvard Business Review, November-December, pp. 98-107.

Wang Ping, Wang Yiji, Hill John (2010) Standardization Strategy of China. Achievements and Challenges, East West Center Working Papers, Economics Series, n. 107, Honolulu.

Windrum Paul, Tomlinson Paul (1999) Knowledge-Intensive Services and International Competitiveness: A Four Country Comparison, Technology Analysis \& Strategic Management, vol. 11, n. 3, pp. 391-408.

http://dx.doi.org/10.1080/095373299107429 